\title{
Analysis of the Development of the Export Seaweed Processing Industry in South Sulawesi
}

\author{
Reza$^{1}, \mathrm{~S} \mathrm{Made}^{2}$, Aris Baso ${ }^{3}$
}

\author{
${ }^{1}$ Student of master Degree Fisheries Science, Faculty og marine and Fisheries Science, Hasanuddin University, Perintis Kemerdekaan St \\ Km 10, makassar 90245, Indonesia \\ ${ }^{2}$ Department of Fisheries Sciences, Faculty of Marine and Fisheries Science, Hasanuddin University, Perintis Kemerdekaan St Km 10 , \\ Makassar 90245, Indonesia
}

\begin{abstract}
This research was conducted in the seaweed industries in South Sulawesi, especially in the Makassar industrial area (KIMA). The purpose of this study is to develop a strategy for developing seaweed commodity processing industries to increase added value. Analysis of the data used is using SWOT analysis. With SWOT analysis, it can produce several alternative strategies in making good decisions to be carried out. So that it can determine the development strategy of the seaweed industry. The results showed an IFAS score of 2.79 and a score for the EFAS results of 2.85. When converted into IE Matrix diagram, it is located in quadrant $V$, where the results of the company enter into the phase of Growth and Stability. The right strategy for companies in quadrant V is SO strategy, using a strategy that utilizes existing opportunities by utilizing the strengths they possess, namely by intensification and extensification of cultivated land, diversification of seaweed processed products and development of fishery products that have high added value including the biotechnology-based industry.
\end{abstract}

Keywords - Seaweed, Industrial Development Strategy, SWOT Analysis, IFAS-EFAS Matrix.

\section{INTRODUCTION}

Seaweed (seaweed) is a marine plant belonging to the multicellular algae (algae) thallophyta division. Unlike perfect plants in general, seaweed has no roots, stems and leaves. Seaweed lives on the ocean floor that can be penetrated by sunlight so it has a variety of colors which are then used to classify seaweed. In general, edible seaweed is a type of blue algae (cyanophyceae), green algae (chlorophyceae), red algae (rodophyceae) and brown algae (phaeophyceae) (Atmadja, 2012). However, the term seaweed is more often used for red algae and brown algae. Brown algae, which is a source of alginate, live mostly in temperate regions.

Seaweed is one of the international trade commodities that have been exported to more than 35 countries. Seaweed cultivation potential in Indonesia is found in provinces such as Aceh, North Sumatra, DKI Jakarta, West Java, Central Java, East Java, Bali, NTT, NTB, North Sulawesi, Central Sulawesi, South Sulawesi, Maluku and Papua (Ministry of Maritime Affairs and Fisheries , 2012). Seaweed as a commodity is also potential to be developed because seaweed cultivation production techniques are relatively easy and inexpensive with very low risk of crop failure, high productivity, and harvests can be done every ISSN: 2456-1878
45-60 days or about 4 times a harvest a year. Seaweed farming can also absorb a large workforce and create large and broad economic multiplier effects. Seaweed is generally traded in the form of: dried seaweed, products that can be directly consumed, and hydrocolloid products.

South Sulawesi is located on the southern peninsula of the island of Sulawesi. The province with its thousand cities in Makassar is administratively, in the north bordering West Sulawesi and Central Sulawesi Provinces. South Sulawesi Province is located at $0^{\circ} 12^{\prime}-8^{\circ}$ South Latitude and $116^{\circ}$ $48^{\prime}-122^{\circ} 36$ 'East Longitude. Its area is $45,764.53 \mathrm{~km}^{2}$ The province is bordered by Central Sulawesi and West Sulawesi to the north, Bone Bay and Southeast Sulawesi to the east, the Makassar Strait to the west and the Flores Sea to the south. Geographically it is located in a very strategic position, because it is at the crossroads of passenger traffic, trade in goods and services from the western region of Indonesia (KBI) to the eastern region of Indonesia (KTI).

With this potential, the amount of production is very large but the absorption of seaweed in the country is still relatively small because most seaweed processing industries in the country are also still limited to the base product level and have not yet developed to the level of end products and product formulations (blended products). 
This resulted in several losses including inefficiency of the seaweed processing industry due to lack of raw materials, loss of potential added value, employment and potential tax revenue. Therefore, seaweed exports in the form of raw materials need to be regulated to ensure the availability of raw materials for the domestic seaweed processing industry that produces end products and formulation products.

Other problems in the seaweed industry in South Sulawesi are the low quality of seaweed produced by farmers, the lack of product diversification, global market requirements, competition between producers, cost efficiency, technology support, waste management (Setyawan, 2018). Based on the foregoing, this research is aimed at determining strategies in the development of the export seaweed processing industry in South Sulawesi.

The purpose of this study is to identify internal factors that are strengths and weaknesses in the development of the export seaweed processing industry in South Sulawesi, identify external factors that are opportunities and threats in the development of the export seaweed processing industry in South Sulawesi. This study also aims to establish alternative development strategies that are appropriate for the export seaweed processing industry in South Sulawesi.

\section{METHOD}

Research activities on the analysis of the development of the export seaweed processing industry are carried out in several seaweed industries in South Sulawesi, particularly in the Makassar industrial area (KIMA). The research location is determined purposively with the consideration that the Makassar industrial area (KIMA) is an industrial center in eastern Indonesia, where there are industrial and warehousing complexes, KIMA houses companies that manage and export seaweed. This research was conducted for 3 months.

\section{Data collection}

Based on the research objectives, the data collected in this study consisted of two sources, namely primary data and secondary data. Primary data is a method of collecting data that is observational through direct observation in the field using several data collection techniques, such as through documentation, filling in questionnaires, and in-depth interviews (Indept Interview) with related parties in accordance with the desired data needs. Secondary data used in this research is to use literature studies or literature studies that are relevant or related to the formulation of the problem and retrieve data that can be obtained from various sources, either through national agencies or through collecting documents that can support this research.

\section{SWOT Analysis}

SWOT analysis is a qualitative analysis to identify various factors systematically and formulate an activity strategy. This analysis is based on logic that maximizes strengths and opportunities, but simultaneously minimizes weaknesses and threats (Rangkuti, 2016).

The steps taken in the SWOT analysis are as follows: (a) Identification of strengths/weaknesses and opportunities/ threats and (b) The analysis stage through mapping the factors identified in the form of the SWOT matrix.

Strategic factors in the development of the export seaweed processing industry in South Sulawesi are arranged in a matrix that can clearly illustrate how external opportunities and threats faced can be adjusted to their strengths and weaknesses. The resulting strategy consists of several alternative strategies. To determine the priority of the strategy that must be chosen, a weighting sum is derived from the interrelationship between the elements of strengths, weaknesses, opportunities, and threats contained in the alternative strategies in the following manner:

a. The SO (Strength and Opportunity) strategy is to add value to the elements of strength and opportunity that are interrelated with the strategy.

b. The WO (Weaknesses and Opportunity) strategy is to add up the value of weaknesses and opportunities that are interrelated with the strategy.

c. The ST Strategy (Strength and Threats) is to add the value of the strength and threat elements that are interrelated with the strategy.

d. The WT (Weaknesses and Threats) strategy is to add the values of weaknesses and threats that are interrelated with the strategy.

Table 1. SWOT Matrix

\begin{tabular}{|c|c|c|}
\hline EFAS & $\begin{array}{c}\text { Strenght } \\
\text { Internal strength } \\
\text { factor }\end{array}$ & $\begin{array}{c}\text { Weaknesses } \\
\text { Internal weakness } \\
\text { factor }\end{array}$ \\
\hline Opportunity & $\begin{array}{c}\text { Strategi SO } \\
\text { Use your strength } \\
\text { to take advantage } \\
\text { of opportunities } \\
\text { factors }\end{array}$ & $\begin{array}{c}\text { Strategi WO } \\
\text { Overcome } \\
\text { advantage of } \\
\text { opportunities }\end{array}$ \\
\hline Ancaman (Threats) & $\begin{array}{c}\text { Strategi ST } \\
\text { Ese force to avoid } \\
\text { threats }\end{array}$ & $\begin{array}{c}\text { Minimize weaknesses } \\
\text { and avoid threats }\end{array}$ \\
\hline
\end{tabular}

Source: Rangkuti, 2016. 
Next do a QSPM analysis. This analysis is an analytical tool that enables strategists to evaluate various alternative strategies objectively, based on important external and internal success factors identified earlier (David, 2011), so as to optimize the results obtained (Zulkarnaen \& Sutopo, 2013). QSPM uses input analysis from the EFAS Matrix, IFAS Matrix and SWOT Matrix to objectively determine the strategy to be carried out among alternative strategies.

\section{RESULTS AND DISCUSSION}

\section{Internal Factor Analysis}

Based on the analysis that has been carried out, some strengths and weaknesses are obtained in the development of the export seaweed processing industry in South Sulawesi. Strengths include : (1) Great seaweed resource potential, (2) Large domestic market with per capita consumption of fishery products and by-products, (3) Government support and regional policies, (4) A large number of the fishing industry. Weaknesses include : (1) Exports of processed seaweed products are still low, (2) Limited supply of raw materials, (3) Seaweed processing technology has not been integrated yet, (4) HR in the seaweed processing industry is still not ready, (5) Infrastructure to support the development of the seaweed processing industry is still limited, (6) The production capacity of the seaweed processing industry is not optimal.

\section{External Factor Analysis}

Based on the analysis, several opportunities and threats were obtained in the development of the export seaweed processing industry in South Sulawesi. Opportunities include : (1) The increasing world consumption needs of fishery products (the size of export opportunities), (2) Opportunities for diversification of marine products, (3) Opportunities for the development of non-food seafood products with high added value, (4) A large quantity of human resources scattered in various centers of marine products. Threats include : (1) Food safety issues, (2) Requirements and standardization of products that refer to international standards, are still difficult to adopt and implement, (3) Export requirements are getting stricter, (4) Very tight competition in obtaining raw materials.

\section{Internal Matrix Analysis}

A weight score of 2.79 indicates that the industry is in a strong position. This means that this industry is relatively stronger in utilizing its strengths and is able to overcome its weaknesses. The main strength of this industry is the potential of large marine resources with a score of 0.56 . In second place is a large domestic market with a score of 0.41. In the third position is government support with a score of 0.33 . In the fourth position is the regional policy with a score of 0.30 and in the fifth position is the large number of the fishing industry with a score of 0.25 . More details can be seen in Table 2 .

Table 2. Results of Internal Factor Analysis

\begin{tabular}{|c|c|c|c|}
\hline \multicolumn{4}{|c|}{ Strength } \\
\hline Factor & Weight & Rating & Score \\
\hline $\begin{array}{l}\text { Large potential of } \\
\text { marine resources }\end{array}$ & 0.14 & 4 & 0.56 \\
\hline 2. Large domestic market & 0.11 & 3.75 & 0.41 \\
\hline 3. Government Support & 0.12 & 2.75 & 0.33 \\
\hline $\begin{array}{ll}\text { 4. A large number of } \\
\text { seaweed industries }\end{array}$ & 0.09 & 2.75 & 0.25 \\
\hline 5. Regional Policy & 0.11 & 2.75 & 0.30 \\
\hline \multicolumn{3}{|c|}{ Total Strength Score } & 1.85 \\
\hline \multicolumn{4}{|c|}{ Weaknesses } \\
\hline $\begin{array}{l}\text { 6. } \\
\text { Exports of processed } \\
\text { seaweed products are } \\
\text { still low }\end{array}$ & 0.07 & 2 & 0.14 \\
\hline $\begin{array}{l}\text { 7. Limited raw material } \\
\text { supply }\end{array}$ & 0.07 & 2.25 & 0.16 \\
\hline $\begin{array}{l}\text { 8. Seaweed processing } \\
\text { technology has not yet } \\
\text { been integrated }\end{array}$ & 0.07 & 2 & 0.14 \\
\hline $\begin{array}{l}\text { 9. Human resources in the } \\
\text { processing industry are } \\
\text { still not ready }\end{array}$ & 0.07 & 2 & 0.14 \\
\hline $\begin{array}{l}\text { 10. Infrastructure is still } \\
\text { limited }\end{array}$ & 0.08 & 2.5 & 0.20 \\
\hline $\begin{array}{l}\text { 11. The production capacity } \\
\text { of the processing } \\
\text { industry is not yet } \\
\text { optimal }\end{array}$ & 0.08 & 2 & 0.16 \\
\hline \multicolumn{3}{|c|}{ Total Weaknesses Score } & 0.94 \\
\hline Total & 1.00 & & 2.79 \\
\hline
\end{tabular}

Source: Primary Data After Processing, 2018

This industry has internal environmental conditions in the form of strengths and weaknesses. The main weakness in the development of the seaweed processing industry in South Sulawesi is that infrastructure is still limited with a score of 0.20 . In the second and third positions are limited supply of raw materials and production capacity of the processing industry which is not optimal with a score of 
0.16. While in the third, fourth and fifth positions are exports of marine products is still low, not yet integrated seaweed processing technology and human resources in the processing industry which are still not ready with a score of 0.14 respectively.

\section{External Matrix Analysis}

Based on the external matrix, the total weighting score is 2.85. This means that the development of the export seaweed processing industry in South Sulawesi is able to respond to external factors by utilizing existing opportunities to overcome threats. The main opportunity in the development of the seaweed processing industry in South Sulawesi is the increasing world consumption needs of seaweed products with a score of 0.53 . The second opportunity is the development of the seaweed industry with high added value with a score of 0.49 . The third opportunity is the diversification of seaweed products with a score of 0.46 and the last opportunity is the quantity of human resources that are numerous and scattered in various centers of marine products with a score of 0.45 . more details can be seen in Table 3 .

Table 3. Results of External Factor Analysis

\begin{tabular}{|c|c|c|c|}
\hline \multicolumn{4}{|c|}{ Oppertunities } \\
\hline Factor & Weight & Rating & Score \\
\hline $\begin{array}{l}\text { 1. The world consumption } \\
\text { needs of seaweed } \\
\text { products are increasing }\end{array}$ & 0.14 & 3.75 & 0.53 \\
\hline $\begin{array}{l}\text { 2. Opportunities for } \\
\text { diversification of marine } \\
\text { products }\end{array}$ & 0.13 & 3.5 & 0.46 \\
\hline $\begin{array}{llr}3 . & \text { Development } \\
& \text { of } \\
& \text { high added value }\end{array}$ & 0.13 & 3.75 & 0.49 \\
\hline $\begin{array}{l}\text { 4. The quantity of human } \\
\text { resources is widely } \\
\text { spread in various centers } \\
\text { of marine products }\end{array}$ & 0.12 & 3.75 & 0.45 \\
\hline \multicolumn{3}{|c|}{ Total Strength Score } & 1.92 \\
\hline \multicolumn{4}{|c|}{ Threats } \\
\hline 5. about food safety & 0.08 & 1.75 & 0.14 \\
\hline $\begin{array}{l}\text { The requirements and } \\
\text { standardization of } \\
\text { seaweed, which refers to } \\
\text { international standards, } \\
\text { are still difficult to adopt } \\
\text { and implement }\end{array}$ & 0.09 & 2 & 0.18 \\
\hline
\end{tabular}

\begin{tabular}{|c|c|c|c|}
\hline $\begin{array}{l}\text { 7. Export requirements are } \\
\text { increasingly stringent }\end{array}$ & 0.08 & 2 & 0.16 \\
\hline $\begin{array}{l}\text { 8. Application of integrated } \\
\text { technology in competitor } \\
\text { countries }\end{array}$ & 0.07 & 1.25 & 0.09 \\
\hline $\begin{array}{l}\text { 9. Very tight competition } \\
\text { in getting raw materials }\end{array}$ & 0.08 & 2.5 & 0.20 \\
\hline $\begin{array}{l}\text { 10. Local products are less } \\
\text { competitive }\end{array}$ & 0.09 & 2.25 & 0.20 \\
\hline \multicolumn{3}{|c|}{ Total Weaknesses Score } & 0.94 \\
\hline Total & 1.00 & & 2.85 \\
\hline
\end{tabular}

Source: Primary Data after Processing, 2018

The development of the export seaweed processing industry in South Sulawesi has external environmental conditions in the form of opportunities and threats. The main threat they have is very tight competition in obtaining raw materials and less competitive local products with a score of 0.20 . The second threat is the seaweed standardization requirements that refer to international standards, are still difficult to adopt and apply with a score of 0.18 . The third threat is the increasingly stringent export requirements with a score of 0.16 and the last threat is the application of integrated technology in competitor countries with a score of 0.09 .

Then an alternative strategy is determined based on a SWOT analysis. From the SWOT matrix, 4 main strategies can be arranged, namely S-O, W-O, S-T, and W-T. Each of these strategies has its own characteristics and should be implemented, then implemented together and support each other (Tjoe and Sarjono, 2010)

- Strategy S-O (Strengths - Opportunities). This category contains various alternative strategies that take advantage of opportunities by utilizing their strengths.

- Strategy W-O (Weaknesses - Opportunities). Categories that take advantage of external opportunities to overcome weaknesses.

- Strategy S-T (Strengths-Threats). An alternative category of strategies that utilize power to overcome threats.

- $\quad$ Strategy W-T (Weaknesses-Threats). An alternative category of strategy is the solution to the assessment of weaknesses and threats faced, or efforts to avoid threats to overcome weaknesses.

Alternative strategies are shown in table 4. Based on the analysis of the SWOT diagram in table 3 and the values in 
the EFAS and IFAS tables, that strength is greater than weaknesses and opportunities are greater than threats then the company is in quadrant 1 with an aggressive strategy that matches the SO strategy in the SWOT matrix.

SWOT matrix and analysis as one of the strategic planning methods used to evaluate strengths, weaknesses, opportunities and threats in fisheries industrialization strategies to support regional economic development. Table 4 outlines the strengths, opportunities, weaknesses, and threats of the fisheries industrialization conditions, resulting in 13 strategies as follows :

1. S1: Strategy 1, Improving the regional economy through increasing the population of the seaweed processing industry
2. S2: Strategy 2, Initiation of the development of seaweed processing industries that have high added value including biotechnology-based industries

3. S3: Strategy 3, Increasing the role of central and regional governments in maintaining food safety of processed seaweed products

4. S4: Strategy 4, Strengthening supply chains, partnerships and market expansion

5. S5: Strategy 5, Adjusting the potential of fisheries resource areas to downstream industries that have high added value

6. S6: Strategy 6, Provision of appropriate equipment and technology

Table 4. Alternative Strategies

1. Large potential marine resources, 1. Exports of processed seaweed including aquaculture and products are still low seaweed

2. Large domestic market

2. Limited supply of raw materials, especially the lean season

3. Government Support

4. A large number of seaweed industries

5. Regional Policy

3. Seaweed processing technology has not yet been integrated

4. Human resources in the seaweed processing industry is still not ready

5. Infrastructure to support the development of the seaweed processing industry is still limited

6. Seaweed processing industry production capacity is not optimal

\section{OPPORTUNITY}

1. Increasing world consumption needs of seaweed products (large export opportunities)

2. Opportunities for diversification of marine products

3. Opportunities for the development of the seaweed industry with high added value

4. Quantity Human resources are abundant and scattered in various centers of marine products

\section{S-O}

- Intensification extensification of cultivated land

- Diversification of processed seaweed products

- Initiation of the development of seaweed industry that has high added value, including biotechnology-based industries

\section{W-O}

- Improve cultivation technique skills to increase production

- Provision of appropriate equipment and technology

- Application of Cultivation Technology

- Increasing the establishment of seaweed industry which has added value and diversification of high products.

- Improvement of processing feasibility certification (SKP) 


\begin{tabular}{|c|c|c|}
\hline THREAT & S-T & W-T \\
\hline $\begin{array}{l}\text { 1. Issues regarding food safety } \\
\text { 2. The requirements and } \\
\text { standardization of fishery } \\
\text { products that refer to } \\
\text { international standards, are still } \\
\text { difficult to adopt and implement }\end{array}$ & $\begin{array}{l}\text { - Increased role of central and } \\
\text { local governments in } \\
\text { maintaining food safety of } \\
\text { processed products } \\
\text { - } \begin{array}{l}\text { Optimizing existing production } \\
\text { capacity }\end{array}\end{array}$ & $\begin{array}{l}\text { - Improving facilities and } \\
\text { infrastructure to support } \\
\text { seaweed industry activities } \\
\text { - Improving quality assurance, } \\
\text { food safety, and improving } \\
\text { sanitation in industry }\end{array}$ \\
\hline $\begin{array}{l}\text { 3. Export requirements are } \\
\text { increasingly stringent }\end{array}$ & $\begin{array}{l}\text { - Improving the quality of } \\
\text { processed seaweed products }\end{array}$ & $\begin{array}{l}\text { Acceleration of the } \\
\text { Development of Fisheries }\end{array}$ \\
\hline $\begin{array}{l}\text { 4. Application of } \\
\begin{array}{l}\text { technology } \\
\text { countries }\end{array}\end{array}$ & $\begin{array}{l}\text { - Strengthening the Supply Chain, } \\
\text { Partnerships and Market } \\
\text { Expansion }\end{array}$ & $\begin{array}{l}\text { Industry Growth Center with } \\
\text { high added value at the locus of } \\
\text { choice }\end{array}$ \\
\hline $\begin{array}{l}\text { 5. Very tight competition in getting } \\
\text { raw materials }\end{array}$ & & \\
\hline $\begin{array}{l}\text { 6. Local products are less } \\
\text { competitive than China, Vietnam } \\
\text { and Thailand }\end{array}$ & & \\
\hline
\end{tabular}

Source: Primary Data After Processing, 2018

7. S7: Strategy 7, Increasing the supply of raw materials through the utilization of fisheries potential in areas with high LQ values

8. S8: Strategy 8, Application of cultivation technology

9. S9: Strategy 9, Increase the establishment of the seaweed industry which has added value and high product diversification.

10. S10: Strategy 10, Improvement of processing feasibility certification (SKP)

11. S11: Strategy 11, Strengthening infrastructure in areas that have high potential but utilization is still low

12. S12: Strategy 12, Improving quality assurance, food safety, and improving sanitation in industry

13. S13: Strategy 13, Acceleration of the development of seaweed industry growth centers with high added value at the locus of choice (optimization of installed capacity of the fishing industry)

\section{CONCLUSION AND RECOMMENDATION}

\section{Conclusion}

The conclusions from the results of research on the analysis of the development of the export seaweed processing industry in South Sulawesi are as follows:
1. Internal factors in the development of the export seaweed processing industry in South Sulawesi as strengths include : (1) Large seaweed resource potential, (2) Large domestic market with per capita consumption of fishery products and byproducts, (3) Government support and regional policies, (4) The number of the fishing industry is large, while the weaknesses include : (1) Exports of processed seaweed products are still low, (2) Limited supply of raw materials, (3) Seaweed processing technology has not been integrated yet, (4) Human resources in the seaweed processing industry are still not ready, (5) Infrastructure to support the development of the seaweed processing industry is still limited, (6) The production capacity of the seaweed processing industry is not optimal.

2. External factors in the development of the export seaweed processing industry in South Sulawesi as opportunities include : (1) The increasing world consumption needs of fishery products (the size of export opportunities), (2) Opportunities for diversification of marine products, (3) Opportunities for the development of non-food seafood products with high added value, (4) A large quantity of human resources scattered in various centers of marine products, while the threats they have include : (1) Food safety issues, (2) Requirements and standardization of products 
that refer to international standards, are still difficult to adopt and implement, (3) Export requirements are getting stricter, (4) Very tight competition in obtaining raw materials.

3. Based on the results of research from the internal side, the analysis of the development of the export seaweed processing industry in South Sulawesi has greater strengths than its weaknesses, while from the external side the opportunities are greater than threats, so the appropriate strategy is the SO strategy, namely using strategies that take advantage of opportunities there is by utilizing the power possessed. What can be done is by way of intensification and extensification of cultivated land, diversification of processed seaweed products and initiation of the development of seaweed industry that has high added value including biotechnology-based industries

\section{Recommendation}

By looking at various problems in the production and processing of seaweed in the country, it is necessary for government policies that encourage the growth and development of seaweed cultivation and seaweed processing industry. Seaweed farmers are advised to be able to produce high quality seaweed periodically by implementing the latest innovations. Related to efforts to improve the quality of Indonesian seaweed, a policy that can be carried out is to apply sea water quality standards for the cultivation and supply of quality seeds. In addition, training can also be done to increase knowledge, cultivation abilities that lead to increased seaweed productivity.

\section{REFERENCES}

[1] Atmadja, W., S. (2012). Apa Rumput Laut itu sebenarnya? Diunduh pada tanggal 12 Juli 2018 dari http://www.coremap.or.id/print/article.php?id=264.

[2] David, F. 2011. Strategic Management, 14th Edition. New Jersey: Prentice Hall.

[3] Kementrian Kelautan dan Perikanan. 2012. DKP Dorong Rumput Laut Sebagai Sumber Pangan dan Energi. Siaran Pers. Jakarta : Kementrian Kelautan dan Perikanan.

[4] Rangkuti, Freddy (2016). Analisis SWOT: Teknik Membedah Kasus Bisnis Cara Perhitungan Bobot, Rating, dan OCAI Cet. Ke-22. Jakarta: PT Gramedia Pustaka Utama.

[5] Setyawan, E.Y. 2018. FGD Struktur dan Kinerja Pemasaran Komoditas Rumput Laut di Sulawesi Selatan. Diunduh pada 31 Juli 2018 pukul 13:28 dari https://kkp.go.id/brsdm/sosek/artikel/7294-fgd-struktur- $\underline{\text { dan-kinerja-pemasaran-komoditas-rumput-laut-di-sulawesi- }}$ selatan

[6] Tjoe, T.F. dan Sarjono, H., (2010), Strategi Bisnis Pada PT. CTL dengan Pendekatan Metode TOWS, Binus Business Review, 1(2), 434-447

[7] Zulkarnaen, H. O. dan Sutopo. 2013. Analisis Strategi Pemasaran pada Usaha Kecil Menengah (UKM) Makanan Ringan (Studi Penelitian UKM Snack Barokahdi Solo). Journal of Managmenet 2 (3): 1-13. Universitas Diponegoro, Semarang. 